\title{
Comparative Analysis of Flour Properties of Dioscorea alata Tuber And Its Utilization On Wet Noodle
}

\author{
Lavlinesia $^{1^{*}}$, Ulyarti $^{1}$, Ade Yulia ${ }^{1}$, Ica Pransisca ${ }^{1}$, Zoles Purnawati ${ }^{1}$ \\ 1. FakultasTeknologi Pertanian, Universitas Jambi \\ * contact person : lavlinesia@unja.ac.id
}

\begin{abstract}
Dioscorea alata grown in many areas of the world has been intensively studied. However none of Indonesian cultivar has been intensively studied for their properties and its utilization in food industry. This research was aimed to compare the properties of purple Dioscorea alata's flour produced using different methods and to study the effect of partly substituted wheat by purple Dioscorea alata's flour on the characteristic of wet noodles. The research on the properties of purple Dioscorea alata's flour was conducted using complete random design with treatment on the methods used to produce flour: control, steaming, soaking in $1 \%$ citric acid solution + steaming, blanching + soaking in $1 \%$ citric acid solution + steaming and blanching + soaking in $2 \%$ ascorbic acid solution + steaming.These 5 methods were repeated 4 times. The research on utilization of Dioscoreaalata's flour on wet noodle was conducted using complete random design with 5 levels of treatment $(0 \%, 10 \%, 20 \%, 30 \%$, and $40 \%$ of Dioscorea alata's flour) and 4 replications. The result showed that steaming the slices of tuber for 7 minutes prior to drying was an effective method to produce flour with strong natural color of purple. The concentration of Dioscorea alata's flour significantly affects the elongation and texture of noodle (p<0.05). Except for its unpleasant grey color, wet noodle can be produced using up to $40 \%$ Dioscorea alata's flour.
\end{abstract}

Keywords -Dioscorea alata's flour, wet noodle, blanching, citric acid, steaming

\section{INTRODUCTION}

Recently, the growing awareness of consumers on therelationship between foods and health has led to an increasing demand for functional foods; foods that provide health benefits further than the basic function of contributing nutrients. Uwi or Yams in English are the edible tubers of various species of the genus Dioscorea. They are important staple foods of many tropical and subtropical countries. Water yam (Dioscorea alata) which referred to as Asian greater yam and ten month yam is potential for functional food. D.alata is a rich source of carbohydrate (81.6- 87.6\%), crude protein content of $7.4 \%$, a good source of vitamin $\mathrm{C}, \mathrm{B} 6$, folate, iron and magnesium (3). It is an excellent source of potassium, with twice the amount found in a medium-sized banana(5).

Water yam (D. alata), is known to contain bioactive compounds such as dioscorine, diosgenin and water soluble polysaccharides (inulin). Dioscorine, the water soluble storage protein of yam, is reported to inhibit ACE (angiotensin converting enzyme) activity (21) which plays an important role in management of hypertension. Diosgenin is a sapogenin steroid compound that can be absorbed through the gut and plays an important role in the control of cholesterol metabolism $(10,25)$. It also shows esterogenic effect (19) and anti tumor activity (22). Inulin is a carbohydrate that serves as an effective prebiotic. Prebiotic is defined as a component of food that cannot be digested by the digestive enzymes.It reaches the colon without changing in the structure and can selectively stimulate the growth and activity of beneficial bacteria in the digestive tract. Inulin is a polymer of fructose units connected by $\beta$ chain $[1,2]$ fruktofuranosida preceded by a single molecule of glucose. Inulin glycosidic bond cannot be hydrolyzed by enzymes present in the digestive system, but can be fermented by the microflora in the digestive tract (probiotic). Inulin may enhance the growth of probiotic (Bifidobacterium, L. casei, L. plantarum), and can inhibit the growth of harmful bacteria such as E. coli and Clostridia.

Water Yam has a lower glycaemic index which makes it a sustainable source of energy and gives better protection against obesity and diabetes (7). The purple color of tubers of Water yam had antihyperlipidemic, antioxidant and antihypertensive activities. Several types of Dioscorea have been used as medicines in oriental countries (23). Angelo et. al. (6) reported that Yam (Dioscorea spp.) has high antioxidant activity. One of the functional compounds of the purple tuber is anthocyanins. Anthocyanins are polyphenolic compounds that perform antioxidant capacity through free radicals scavenging mechanism (9). Recent research indicates that anthocyanins have physiological benefits related to the circulating-organ function (15), improved blood lipid profiles by increasing plasma High Density Lipoprotein (HDL) and lowering LDL (Low Density Lipoprotein). Winarti et. al (28) reported that tubers of Dioscorea contain inulin. Among 10 types of wild yams, the highest level of inulin $(14.77 \%, \mathrm{db})$ was found in Dioscororea esculenta (gembili).

Dioscorea spp.which grows well in Indonesia is known as Uwi. It is a kind of tuber that has not been utilised optimally. None of Indonesian cultivar has been intensively studied for their properties and its utilization in food industry.There are two varieties of water yam based on their 
flesh color: purple (Dioscorea alata L. var. purpurea (Roxb) M. Pouch) and yellow (Dioscorea alata L.). In order to extend the shelf life and utilization, fresh tubers are usually processed into flour as an intermediate product. Purple water yam flour has a high peak viscosity and more stable to heat. It is better to be processed as a functional food due to its greater content of bioactive compounds (14). D. alata var. Purpurea had been incorporated into noodle to produced noodle with hypolipidemic and antioxidative effects, while maintaining sensory characteristics (20). Adeleke and Odedeji (2) reported that water yam flour was used as composite flour with wheat in the production of bakery products such as cookies, bread and cakes to reduce the cost of production.

One potential problem in the processed yam flour is the discoloration and darkening of the product (24). This may be undesirable to many people. This has been attributed to enzymic browning reactions as a result of the presence of water soluble phenolic substances in yam. The phenomena of enzymatic browning have long been a source of concern to food scientist. Various approaches have been applied in preventing browning of yam during processing into flours. These approaches include inactivating the phenolase by blanching or use of inhibitors (4), rendering the conditions unfavorable to enzyme action by lowering $\mathrm{pH}$ using inorganic acids, minimizing contact with oxygen and the use of antioxidants such as ascorbic acid or sulphur dioxide e.t.c (16) either individually or in combinations among them.However, an efficient method for application to prevent browning has not been found yet.

Sodium metabisulphite was completely inhibited browning in the processed yam flour (12). Immersing yam tubers in sodium metabisulphite solution ( $800 \mathrm{ppm}$ for $20 \mathrm{~min}$ ) followed by blanching at $70^{\circ} \mathrm{C}$ for $10 \mathrm{~min}$ recorded higher sensory scores than the one blanched for $5 \mathrm{~min}$. Harijono et al., (14) reported that steam blanching $\left(97 \pm 2^{\circ} \mathrm{C}, 7 \mathrm{~min}\right)$ on the purple cultivar resulted in more significant reduction on yield and the Lightness (L) value of the flour compared with the unblanched sample. Adejumo et al.,(1) recommended that the best combination of processing parameter for best quality yam flour is $40^{\circ} \mathrm{C}$ blanching water temperature and $12 \mathrm{~h}$ soaking time. The yam flour produced from blanched and soaked yam cubes has better quality attributes than the unblanched and unsoaked samples.

This research work was therefore designed to study the effect of some methods on the reduction of browning to improve of the product thereby increasing the general acceptability of purple yam flour. The objectives of this research were to compare the properties of purple Dioscorea alata's flour produced using different methods and to study the effect of partly substituted wheat by purple yam flour on the characteristic of wet noodles.

\section{MATERIAL AND METHODS}

\section{A. Material}

The fresh tubers of purple Dioscorea alata was harvested in two areas in Jambi Province: Kerinci and
Bangko. Randomly selected mature tubers of Purple water yam (Dioscorea alata L. var. purpurea (Roxb) M. Pouch) were collected from local farmers. The tubers were stored at room temperature $\left(30^{\circ} \mathrm{C}\right)$, until further required.

\section{B. Methods}

\section{Flour preparation:}

Fresh yam tubers (D. alata L) without rot and decay were randomly selected and cleaned carefully using sponge followed by washing with tap water and divided into five parts. The experiment was carried out using Complete Random Design using treatment on methods of flour production and carried out using five method :

Control(C): The tubers were peeled, sliced, and dried in the oven at $60^{\circ} \mathrm{C}$ for 6 hours.

Steaming(S): The tubers were peeled, sliced, steamed for 7 minutes and dried in the oven at $60^{\circ} \mathrm{C}$ for 6 hours.

Citric acid + steaming(CS): The tubers were peeled, sliced, soaked in $1 \%$ citric acid solution for 30 minutes, steamed for 10 minutes and dried in the oven at $60^{\circ} \mathrm{C}$ for 6 hours.

Blanching + citric acid + steaming (BCS): The tubers were peeled, soaked in warm water for 10 minutes, sliced, soaked in $1 \%$ citric acid solution for 30 minutes, steamed for 10 minutes and dried in the oven at $60^{\circ} \mathrm{C}$ for 6 hours.

Blanching + Ascorbic acid + steaming (BAS): Similar to BCS treatment, but using $2 \%$ ascorbic acid solution in place of citric acid solution.

All dried chips were respectively ground to pass 60 mesh standard sieves. The flour was packed and sealed in 8 mm-thick polypropylene and stored at $0 \pm 2{ }^{\circ} \mathrm{C}$ until used. Each method was repeated four times.

Physical and chemical analysis of flour: The colours of flour were measured using $\mathrm{L}^{*}$ (lightness), $\mathrm{a}^{*}$ (redness), $\mathrm{b}^{*}$ (yellowness) value using simple digital imaging. Total anthocyanin the flours were determined using $\mathrm{pH}$ difference method by Steed and Troung (2008).

\section{Noodles Preparation}

Steaming method (S)was used to prepare purple $D$. alata's flour except for drying process which used sun drying instead of oven drying. For this purpose, D. alata's tuber from Kerinci was used. Noodles were made according to the method as suggested by Astawan (7). Noodles were made from wheat flour blends with purple yam flour at various levels $(0 \%, 10 \%, 20 \%, 30 \%$, and $40 \%)$ as the treatment. The experiment was performed using Complete Random Design and repeated four times. The making process consists of mixing, resting, sheeting, and cutting. The noodle was produced using 200 gram of formulated flour, 2 gram salt, 15 gram egg yolk, $0.6 \%$ kie water and $10 \%$ water (calculated from the total amount of flour).

After all the ingredients were blend and mixed the process was followed by kneading by hand, rolling and folding for 25 minutes. This is required to form the dough matrix and homogenize its ingredients. After that, the dough was spread to form sheets with approximately $1,2 \mathrm{~mm}$ thick, 
placed into acrylic plates $(15 \times 16 \mathrm{~cm})$ and rested for one hour.The purposes of resting are for water dispersion and gluten formation in the dough. Resting the dough for a long time will result in softer noodle dough than can be stretched. Noodles sheets were then cut into strips with $3.0 \mathrm{~mm}$ with pasta maker. The strands were dusted with tapioca flour and boiled for 2 minutes to complete gelatinization and then cooled to room temperature. Little vegetable oil was added to the boiled water to prevent the strands stick to each other.

\section{Analysis of Noodle}

Noodles samples were studied for tensile strength, color and sensory evaluation (texture and overall acceptance). Color of noodle was analyzed for its $\mathrm{L}^{*}, \mathrm{a}^{*}$, and $\mathrm{b}^{*}$ color using simple digital imaging. Elongation was measured simply by pulling the noodle strain until it breaks. Texture and overall acceptance of noodle were examined by 20 semiskilled panelists using 5 scales.

\section{Statistical analysis}

The data was analyzed using analysis of variance(ANOVA) and when found to be different the analysis was continued using Duncan's multiple range test.

\section{RESUlt AND DisCUSSION}

\section{Physical and chemical characteristics of flour:}

The colors of flour produced using 5 different treatments are shown in Table 1. The effect of the treatment on $\mathrm{L}^{*}$ value of flour was significant while its effect on " $\mathrm{a}$ *" and " $b$ " " values were highly significant. The average values of $\mathrm{L}^{*}$, " $\mathrm{a}$ *" and " $\mathrm{b}$ " " are shown in Table 1. $\mathrm{L}^{*} \mathrm{a} \mathrm{b}^{*}$ " is color scale which assume that the receptor in human eyes perceives color as pairs of opposite: light versus dark ( $\mathrm{L}^{*}$ value), red versus green (a* value), and yellow versus blue ( $b^{*}$ value). A low number $(0-50)$ of " $\mathrm{L}^{*}$ " indicates dark while, a high number (51-100) indicates light. Positive value of " $a *$ " indicates red while negative value indicates green. Positive value of " $b$ " indicates yellow while negative value indicates blue. A three dimensional representation of the value of $\mathrm{L}^{*}$, "a*" and " $b$ *"gave color as shown in Table 1. The lower " $b$ *" value indicates the stronger purple color and this showed by treatment using citric acid + steaming (CS) followed by steaming treatment $(\mathrm{S})$, blanching + citric acid + steaming (BCS), blanching +ascorbic acid + steaming (BAS) and control (C).

Ascorbic acid is shown to be ineffective to lower the brownish color of the flour. This result agrees with previous study on potato, greater yam and white yam (18). The treatment with ascorbic acid in present study increased the " $b$ *" value close to control. Blanching is a short and mild heat treatment prior to the main process for the purpose of enzymes inactivation. Hot water and steam are the most commonly used heating media for blanching in industry (11).Similar to ascorbic acid, blanching with hot water prior to the treatment in BCS and BAS methods were also not enough to inactivate polyphenoloxidases and peroxidases.Control of browning occurred at citric acid and steaming (CS) and steaming (S) treatment which was indicated by the lowest value of " $b$ *" although both treatments was not statistically significant (see Table 1).Comparing statistical analyzes of the flour produced using steaming (S) and citric acid + steaming (CS), it was shown that the used of citric acid in the treatment didn't produce different color of flour in terms of all color parameters (Table1). Therefore according to this result, the most effective treatment suggested to produce flour was steaming (S). Similar result on CS flour was reported by (27) in which purple tubers of $D$. alata from the same area (Bangko, Jambi Province) was used.

Table 1. Color value of purple Dioscorea alata"s flour produced using 5 different methods

\begin{tabular}{|c|c|c|c|c|c|}
\hline \multirow{2}{*}{$\begin{array}{l}\text { flour } \\
\text { proces }\end{array}$} & \multicolumn{3}{|c|}{ Color value } & \multirow{2}{*}{$\begin{array}{l}\text { Color } \\
\text { of flour }\end{array}$} & \multirow[t]{2}{*}{ Color } \\
\hline & $\mathrm{L}^{*}$ & $a^{*}$ & $\mathrm{~b}^{*}$ & & \\
\hline $\mathrm{C}$ & $60.67 a$ & $0.67 \mathrm{a}$ & $3.67 \mathrm{a}$ & & $\begin{array}{c}\text { Dark grayish } \\
\text { orange }\end{array}$ \\
\hline $\mathrm{S}$ & $58.00 \mathrm{ac}$ & $15.33 b$ & $-15.33 b c$ & & $\begin{array}{c}\text { Dark grayish } \\
\text { violet. }\end{array}$ \\
\hline $\mathrm{BCS}$ & $58.67 \mathrm{ac}$ & $38.67 d$ & $-12.33 c$ & & $\begin{array}{c}\text { Slightly } \\
\text { desaturated } \\
\text { pink. }\end{array}$ \\
\hline BAS & $67.00 \mathrm{~b}$ & $18.67 \mathrm{c}$ & $2.67 \mathrm{a}$ & & Grayish red. \\
\hline $\mathrm{CS}$ & $56.67 \mathrm{c}$ & $16.67 \mathrm{bc}$ & $-21.00 b c$ & & $\begin{array}{c}\text { Mostly } \\
\text { desaturated } \\
\text { dark violet }\end{array}$ \\
\hline
\end{tabular}

$\mathrm{C}=$ Control, $\mathrm{S}=$ steaming, $\mathrm{CS}=$ Citric acid + steaming, $\mathbf{B C S}=$ Blanching + citric acid + steaming, BAS $=$ Blanching + Ascorbic acid + steaming

Means within a column with the same letters are not significantly different $(p \geq 0.05)$ by ANOVA and DMRT.

Statistical analysis showed that the method of producing flour affected the water content and total anthocyanin of the flour (Table 2.). All of methods used in this experiment were significantly increase the total anthocyanins in the purple yam's flour compared to control. The flour produced using steaming (S) the slices of purpled. D.alata tubers had the highest value of total anthocyanins of all methods used in this experiment, followed by citric acid soaking and steaming (CS). Soaking tuber in both acid solutions which aimed to render the condition unfavorable for enzymatic browning was unfortunately cause anthocyanin leaching from the flour. The leaching of anthocyanin was further occurred when blanching was used (BAC and BAS). 
Table 2.Rendement, moisture content and total anthocyanins of purpled $D$. alata"s flour produced using 5 different methods

\begin{tabular}{|c|c|c|c|}
\hline Method & $\begin{array}{c}\text { Rendement } \\
\text { of flours }(\%)\end{array}$ & $\begin{array}{c}\text { Water } \\
\text { content }(\%)\end{array}$ & $\begin{array}{c}\text { Average total } \\
\text { anthocyanins }\end{array}$ \\
\hline S & $\mathbf{1 0 . 8 5}$ & $7,80 \mathrm{a}$ & $175.53 \mathrm{a}$ \\
CS & 9.48 & $\mathbf{8 , 6 2} \mathrm{b}$ & $115.13 \mathrm{~b}$ \\
BCS & 10.31 & 7,56 bc & $88.57 \mathrm{c}$ \\
BAS & 8,46 & 7,58 bc & $60.61 \mathrm{~d}$ \\
C & 9.40 & $7,34 \quad \mathrm{c}$ & $38.53 \mathrm{e}$ \\
\hline
\end{tabular}

Means within a column with the same letters are not significantly different $(p \geq 0.05)$ by ANOVA and DMRT.

\section{Physical characteristic of wet noodles}

\section{Colour of wet noodles}

Wet noodles produced from present experiment are presented in Tabel 3. The greyish color was increasing as the concentration of purple $D$. alata's flour increased. The grey color was resulted from basic characteristic of kie water (alkali water or q-water). Alkali water was used in noodle making to increase the elasticity and extensibility and to soften the noodle's texture. Alkali water is a solution mixture of sodium carbonate $\left(\mathrm{Na}_{2} \mathrm{CO}_{3}\right)$ and potassium carbonate $\left(\mathrm{K}_{2} \mathrm{CO}_{3}\right)$. The alkali water during formation of dough can release $\mathrm{CO}_{2}$, causing the dough to expand.

Table 3.Colour of wet noodles produced at different concentration of purple $D$. alata's flour

\begin{tabular}{|c|c|c|c|c|}
\hline \multirow{2}{*}{$\begin{array}{c}\text { Purple } \\
\text { of } \\
\text { flours } \\
(\%)\end{array}$} & \multicolumn{3}{|c|}{ Colour value } & \multirow{2}{*}{ Colour } \\
\cline { 2 - 4 } & $\mathrm{L}^{*}$ & $\mathrm{a}^{*}$ & $\mathrm{~b}^{*}$ & Very soft orange \\
\hline 0 & $83.67 \mathrm{a}$ & $3.33 \mathrm{a}$ & $20.00 \mathrm{a}$ & $\begin{array}{c}\text { Dark grayish lime } \\
\text { green }\end{array}$ \\
\hline 10 & $62.67 \mathrm{~b}$ & $-5.00 \mathrm{~b}$ & $2.67 \mathrm{~b}$ & $\begin{array}{c}\text { Very dark grayish } \\
\text { cyan }\end{array}$ \\
\hline 20 & $46.67 \mathrm{c}$ & $-3.67 \mathrm{bc}$ & $-0.33 \mathrm{c}$ & $\begin{array}{c}\text { Very dark grayish } \\
\text { cyan }\end{array}$ \\
\hline 30 & $39.67 \mathrm{~d}$ & $-3.67 \mathrm{bc}$ & $-2.33 \mathrm{c}$ & $\begin{array}{c}\text { Very dark grayish } \\
\text { cyan }\end{array}$ \\
\hline 40 & $37.33 \mathrm{~d}$ & $-3.33 \mathrm{c}$ & $-6.33 \mathrm{~d}$ & \begin{tabular}{c} 
Ven \\
\hline
\end{tabular} \\
\hline
\end{tabular}

Means within a column with the same letters are not significantly different $(\mathrm{p} \geq 0.05)$ by ANOVA and DMRT.

Antocyanin, which was recognized as the component who gives the purple color of purple D. alata's flour (13) is sensitive to $\mathrm{pH}$. At neutral condition, anthocyanin gives purple. Changes in $\mathrm{pH}$ to more acidic or basic will change the purple color depend on type of anthocyanin present in the material. In the case of noodles made out of purple

D. alata's the color changed into dark grey. This is the most apparent disadvantage obtained from production of wet noodle using alkali water. Noodles prepared without alkali water showed to have pleasant purple (27).

\section{Elongation of wet noodle}

Elongation of wet noodle produced using $100 \%$ wheat ( $0 \%$ purple $D$. alata's flour) in the present experiment was lower than expected. A study showed elongation for $200 \%$. The main reason for this is in the kneading process in which hand kneading did not produce dough as elastic as kneading using electric kneader. The concentration of purple $D$. alata's flour significantly affected the elongation of wet noodle. The elongation was decreased as the concentration of purple $D$. alata's flour increased. In term of elongation, the use of $10 \%$ purple $D$. alata's flour produced wet noodle which was different from control, but was not different from the other treatments using higher concentration of purple $D$. alata's flour (see Table 4). The basic differences between purple D. alata s flour and wheat flour are D. alata's flour doesn't contain gluten which is required to improve the elasticity of the noodle. Gluten is a protein compound in wheat flour that gives elasticity and extensibility in noodles. Gluten gives the dough its viscoelasticity and makes the end product chewier. Gluten is a kind of protein, which consists of glutenin and gliadin. These proteins affect the elasticity of the noodle dough. Glutenin is a component that can increase the density and strength of the dough, because it increases the stability by a three-dimensional network that forms upon the development of the sulfur cross-linkage between the proteins in the dough making process. Gliadin is a glycoprotein component that is needed to improve and strengthen the dough. In the water, starch molecules will form a matrix with gluten.

Table 4. Elongation, crude fibre and water content of wet noodle produced using different concentration of purple Dioscorea alata's flour.

\begin{tabular}{|c|c|c|c|}
\hline $\begin{array}{c}\text { Purple } \\
\text { D. alata's } \\
\text { flour (\%) }\end{array}$ & $\begin{array}{c}\text { Average of } \\
\text { elongation }(\%)\end{array}$ & $\begin{array}{l}\text { Average of } \\
\text { crude fiber } \\
\text { content }(\%)\end{array}$ & $\begin{array}{c}\text { Average of } \\
\text { water } \\
\text { content } \\
(\%)\end{array}$ \\
\hline 0 & $137.0 \mathrm{a}$ & 0.85 & $47.64 \mathrm{~b}$ \\
\hline 10 & $131.5 \mathrm{ab}$ & 0.98 & $48.74 \mathrm{ab}$ \\
\hline 20 & $127.0 \quad b$ & 1.03 & $49.31 \mathrm{ab}$ \\
\hline 30 & $124.5 \quad b$ & 1.17 & $52.0 \quad \mathrm{ab}$ \\
\hline 40 & $122.5 \mathrm{~b}$ & 1.37 & $54.83 \mathrm{a}$ \\
\hline
\end{tabular}

Means within a column with the same letters are not significantly different $(\mathrm{p} \geq 0.05)$ by ANOVA and DMRT.

Eventhough statistically insignificant, the average of crude fiber content $(\%)$ in Table 4 shows that as the amount of purple $D$. alata's flour increase, the crude fiber content in the noodles increased too. The crude fiber content was increasing from $0.85 \%$ in control ( $100 \%$ wheat flour) to $1.37 \%$ in $40 \%$ purple D. alata's flour.

\section{Analysis sensory}

The mean values of the hedonic scores for sensory attributes of wet noodles samples are shown in Table 5. Statistical analysis indicated significant $(\mathrm{p}<0.05)$ difference between the noodles samples prepared form the various 
substitution of wheat.The amount of purple D. alata's flour used partly to replace wheat flour affected the sensory acceptability of texture and overall acceptance, but not affected to taste of wet noodles. The textural qualities of the wet noodles highly were significantly affected by the concentration of purple $D$. alata's flour. The texture of wet noodles decreased with increased concentration of purple $D$. alata's flour.

Table 5: Sensory attributes of wet noodles produced at different concentration of purple $D$. alata's flour

\begin{tabular}{|c|cr|c|cc|}
\hline $\begin{array}{c}\text { Purple } \\
\begin{array}{c}\text { D. alata's flour } \\
\text { (\%) }\end{array}\end{array}$ & \multicolumn{2}{|c|}{ Texture } & Taste & \multicolumn{2}{c|}{$\begin{array}{c}\text { Overall } \\
\text { acceptability }\end{array}$} \\
\hline 0 & 3.90 & $\mathrm{a}$ & 3.90 & 4.35 & $\mathrm{a}$ \\
10 & 3.60 & $\mathrm{~b}$ & 3.80 & 3.80 & $\mathrm{~b}$ \\
20 & 3.30 & $\mathrm{c}$ & 3.55 & 3.70 & $\mathrm{bc}$ \\
30 & 3.20 & $\mathrm{~d}$ & 3.40 & 3.70 & $\mathrm{c}$ \\
40 & 3.15 & $\mathrm{~d}$ & 3.30 & 3.35 & $\mathrm{~d}$ \\
\hline
\end{tabular}

Scored for:

Texture: $1=$ extremely inelastic $2=$ inelastic $3=$ elastic slightly $4=$ elastic $5=$ extremely elastic

Taste $: 1=$ dislike extremely, $2=$ dislike, $3=$ like, $4=$ like, $5=$ like extremely

Overall acceptance:

$1=$ dislike extremely, $2=$ dislike, $3=a$ little bit like, 4=like,

$5=$ like extremely

The statistical analysis regarding the overall acceptability of wet noodle prepared from wheat substitution with purple D. alata's flour is shown in Table 5. The result shows that substitution significantly affected the overall acceptability of wet noodles. The value ranged from $4.35-$ 3.36; there were significant difference $(\mathrm{p} \geq 0.05)$ between control $(0 \%)$ and other sample, also there was significant for each other. Maximum score of 4.35 was prepared from $100 \%$ wheat flour, while minimum score 3.35 was scored by the noodles prepared $40 \%$ purple $D$. alata's flour substitution, its mean up to $40 \%$ purple $D$. alata's flour substitution wet noodles can be acceptance by panelist.

\section{Conclusion}

It could be concluded that steaming method can retain the color of flour hence produce stronger natural color of purple. The substitution of wheat flour with purple Dioscorea alata's flour in wet noodle with substitution up to $40 \%$ affected the quality properties: color, texture, and \% elongation of wet noodle. Substitution up to $20 \%$ produced noodles with very dark grayish. Except for its unpleasant color, substitution of up $40 \%$ wheat flour with purple Dioscorea alata's flour was accepted.

\section{REFERENCES}

[1] Adejumo, A.L., A.F. Aderibigbe and S.K. Layokun. Cassava starch: Production, physicochemical properties and hydrolisation-A review. Adv. Food Energy Secur., vol. 2, ed. 01, pp. 8-17. 2011

[2] Adeleke, R.O. and J.O. Odedeji. Functional properties of wheat and sweet potato flour blend. Pak. J. Nutr., vol 9, ed.6: pp. 535-538. 2010
[3] Afoakwa, E. O. and S. Sefa-Dedeh. Chemical composition and quality changes occurring in Dioscorea dumetorum pax tubers after harvest. Food Chemistry, vol. 75, pp. 85-91. 2001

[4] Akubor. Effect Ascorbic Acid and Citric Acid Treatments on The Functional and Sensory Properties of Yam Flour. Int. J. Agric. Pol. Res, vol. 1, ed. 4, pp.103-108. 2008.

[5] Albrecht M. A. and McCarthy, B. C. Seed Germination and Dormancy in The Medicinal Woodland Herbs Collinsonia Canadensis L. (Lamiacacaea) and Dioscorea Villosa L. (Discoreacae), Flora, vol. 201, pp. 24-31. 2006

[6] Angelo J.ML, Antonio C.L and Evelyn Mae TecsonMendoza.Atioxidants of purple and White Greater Yam (Dioscorea alata L) Varietas from the Philippines.Philippine Journal of Science 137 (1):61-67, Juni 2008

[7] Astawan, M. Membuat Mi dan Bihun. Penebar Swadaya, Jakarta. 2001.

[8] Brand-miller J., J. Burani and K. Foster-Powell. The New Glucose Revolution Pocket Guide to the Top 100 GI Foods. 2003.

[9] Chaovanalikit A, and RE Wrolstad. Total anthocyanins and total phenolics of fresh and processed cherries and their antioxidant properties. J Food Sci, vo. 69, pp. FCT67-FCT72. 2004.

[10] Chapagain, B. and Z. Wiesman. Variation in diosgenin level in seed kernel among different provenances of balanites aegyptiaca del (Zygophyllaceae) and its correlation with oil content. Afr. J. Biotechnol., vol. 4, ed. 11, pp. 1209-1213. 2005.

[11] Corcuera, J.I.R., R.P. Cavalieri and J.R. Powers.. Blanching of Foods, In: Encyclopedia of Agricultural, Food and Biological Engineering. Marcel Dekker Inc., Retrieved from: http://www. Dekker.com. 2004

[12] Evans E.C., G. Yakubu, Bello, and T. Annals. Evaluation of ascorbic acid and sodium metabisulphite as Inhibitors of browning in yam $(D$. rotundata) flour processing. Food Science and Technology. 2013

[13] Fang Zhogxiang, Wu Dan, Yu Dong, Ye Xinqian, Liu Donghong, Chen Jianchu. . Phenolic compounds in Chinese purple yam and changes during vacuum frying. Food Chemistry,vol. 128:pp.943-948. 2011

[14] Harijono, Estiasih, T., Saputri, D., dan Kusnadi, J. Effect of Blanching on Properties of Water Yam (Dioscorea alata) Flour. Adv. J. Food Sci. Technol, vol. 5, ed.10, pp.1342-1350. 2013.

[15] Hassellund SS, Flaa A, Kjedsen SE, Seljeflot I, Karsen A, Erlund I, Rostrup M. The Effects of anthocyanins on cardiovascular risk factors and inflammation in prehypertensive men: a double-blind randomized placebo-controlled crossover study. J Hum Hypertens vol. 27, pp. 100-106. 2013.

[16] Jiang, Y., and J. Fu. Inhibition of Phenol Oxidase and The Browning Control of Litchi Fruit by Glutethionine and Citric Acid. Food Chem, vol. 62, pp. 49-59. 1998.

[17] Kirca A, M. Ozkan, amd B Cemerogu. Effect of temperature, solid content and $\mathrm{pH}$ on the stability of black carrot anthocyanins. Food Chem, vol. 101, pp. 212-218. 2007.

[18] Krishnan JG, Padmaja G, Moorthy SN, Suja G, Sajeev MS. Effect of pre-soaking treatments on the nutritional profile and browning index of sweet potato and yam flours. Innov Food Sc Emerg vol 11, pp.387393.2010.

[19] Li, P., Y. Mou, S. Lu, W. Sun, J. Lou, C. Yin and L. Zhou. Quantitative determination of diosgenin in D. zingiberensis cell cultures by microplate-spectrophotometry and HPLC. Afr. J. Pharm. Pharmacol., vol. 6, ed. 15, pp. 1186-1193. 2012.

[20] Lin, C.L., S.Y. Lin, Y.H. Lin and W.C. Chou. Effects of tuber storage protein of yam (Dioscorea alata cv. Tainong No. 1) and its peptic hydrolizates on spontaneously hypertensive rats. J. Sci. Food Agric., vol 86, pp. 1489-1494. 2006.

[21] Liu, Y.W., H.F. Shang, C.K. Wang, F.L. Hsu and W.C. Hou. Immunomodulatory activity of dioscorin, the storage protein of yam (Dioscorea alata cv. Tainong No.1) tuber. Food Chem. Toxicol., vol. 45, pp. 2312-2318. 2007 
[22] Moalic, S., B. Liagre, C. Corbiere, A. Bianchi, M. Dauca, K. Bordji and J.L. Beneytout. A plant steroid, diosgenin induces apoptosis, cell cycle arrest and cox activity in osteosarcoma cells. FEBS Lett., vol. 506, pp. 225-230. 2001.

[23] Nagai, T., N. Suzuki, and T Nagashima. Antioxidative activity of water extracts from the yam (Dioscorea opposite Thumb.) tuber mucilage tororo. Eur j Lipid Sci Tech, vol. 108, pp. 5-531. 2006.

[24] Onayemi D, and N.N Potter. Preparation and properties of drum dried white yam (Dioscorea rotundata piri) flakes. J of Food Sci, vol. 39, pp.559-610. 1974.

[25] Roman, T.D., A. Thawles and R. Coleman. Fractionation of livers following diosgenin treatment to elevate biliary cholesterol. Biochim. Biophys. Acta, vol. 1225, pp. 77-81. 1995.

[26] Steed, L.E. and V.D.Truong. Anthocyanin content, antioxidant activity and selected physical properties of flowable purple-fleshed sweetpotato purees.Journal of Food Science Vol 73 (5), 2008.

[27] Ulyarti, Dewi Fortuna, Indryani. 2015. Pembuatan mie basah dari umbi uwi (Dioscore aalata) yang berpotensi sebaga imakanan yang baik bagi penderita diabetes (indeks glikemik rendah). Laporan Penelitian Kelompok Universitas Jambi.

[28] Winarti, S., E. Harmayani, and R. Nurismanto. Karakteristik dan Profil Inulin beberapa Jenis Uwi. Agritech, vol. 31, ed. 4, pp. 378-383. 2011. 